\title{
Worldwide Inflation and International Monetary Reform: Exchange Rates or Interest Rates?
}

\author{
Ronald McKinnon*
}

\begin{abstract}
The international dollar standard is malfunctioning. Near-zero US short-term interest rates launch massive hot money outflows into emerging markets (EM) in Asia and Latin America. Each EM central bank buys dollars to prevent its currency from appreciating but loses monetary control. Despite some appreciation, average inflation in EMs is now much higher than in the old industrial economies and world commodity prices are bid up sharply. This inflation on the dollar's periphery only registers in the US CPI with a long lag. However, the more immediate effect of the Fed's zero interest rate is to upset the process of bank intermediation within the American economy. Bank credit continues to decline while employment languishes. Therefore, constructive international monetary reform calls for the Fed to abandon its zero-interest rate policy, which is best done in cooperation with the European Central Bank, the Bank of Japan, and the Bank of England also abandoning their ultra low interest rates.
\end{abstract}

K ey words: exchange rate, global inflation, international monetary reform, interest rate J E L codes: E43, F31, F33

\section{Introduction}

In reforming the international monetary system, exchange rates usually receive front and center attention, such as at the numerous meetings of the Group of 20 (G-20). Nobody wants a replay of the destructive beggar-thy-neighbor exchange rate depreciations of the 1930s.

However, at the G-20 meeting in November 2010, President Obama attacked China for

\footnotetext{
* Ronald McKinnon, Professor of Economics, Stanford University, Stanford, US. Email: mckinnon@stanford.edu.
} 
Figure 1. Exchange Rate Valuations
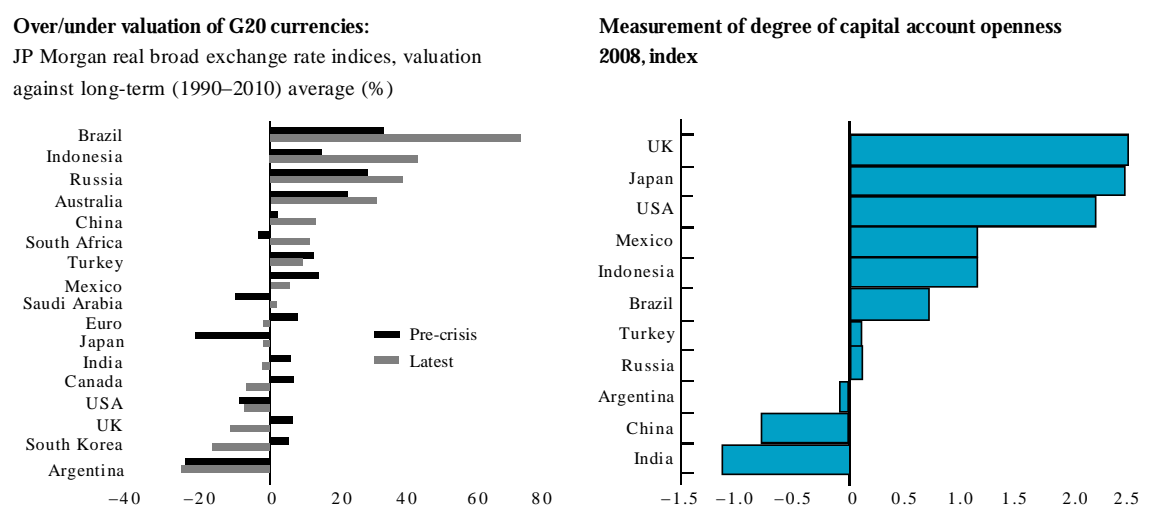

Source: Financial Times, 11 November 2010.

not appreciating. In the dollar-based world of East Asia, China's monetary policy has been oriented toward keeping the yuan/dollar rate fairly stable since 1994, when China unified its exchange rate system and went to current-account convertibility under the IMF's Article VIII. This policy of exchange rate stability served China well as a nominal anchor for its domestic price level, and to balance exchange relationships with its smaller neighbors (McKinnon and Schnabl, 2011). In addition, the left-hand panel of Figure 1 shows no clear evidence that China's exchange rate is undervalued vis-à-vis Europe or the USA relative to their "real" multilateral exchange rates averaged over the past 20 years.

Not finding any agreement on exchange rate practices, the G-20 meetings shifted to trade imbalances. Last November, the USA suggested that countries with trade surpluses cap them at, say, 4 percent of GDP. However, trade surpluses simply reflect net saving surpluses: the difference between national saving and investment. In market economies, governments do not directly control either, nor, contrary to popular opinion and the proponents of "China bashing" to appreciate the RMB, can exchange appreciation be used as an instrument to reduce any creditor country's saving (trade) surplus (Qiao, 2007; McKinnon and Schnabl, 2009).

Moreover, the USA weakened its position by not following through: it did not pledge to eliminate its saving deficiency, that is, to reduce its fiscal deficit and to raise the woefully deficient saving of American households. But eventually, for global imbalances to be corrected, surplus countries must consume more while the saving-deficient US consumes much less. However, in view of the dramatic November impasse of the G-20 and continuing stalemate in 2011 on exchange rate and US fiscal issues, better to let sleeping dogs lie. 


\section{Interest Differentials, Carry Trades and Worldwide Inflation}

With exchange rates and trade balances off the table for now, what remains for constructive international monetary reform? Almost all emerging markets (EM) at the G-20 meeting in November 2010, and even more now in 2011, complained about ultra-low interest rates at the "center" inducing hot money flows to the "periphery". With today's two-speed world recovery, the slowly growing mature industrial countries (the USA, Japan and European countries) have cut short-term interest rates very low. Figure 2 shows short-term interbank interest rates in the US to be near zero since the end of 2008, and Japan has been stuck in a zero-interest liquidity trap since the mid-1990s. In addition, the US Federal Reserve's “Quantitative Easing” for reducing long rates (ending in June 2011) exacerbated the problem. In 2010-2011, the resulting "carry trade" has induced a flood of hot money into EM, which have higher growth and naturally higher interest rates.

Although interrupted by the credit crunch in the last half of 2008 into 2009 when the crisis demand for dollars shot upward, the dollar's trade-weighted nominal exchange rate has been depreciating since 2002 through 2011 (Figure 3). The main pressure comes from

Figure 2. US Short-term Interest Rate

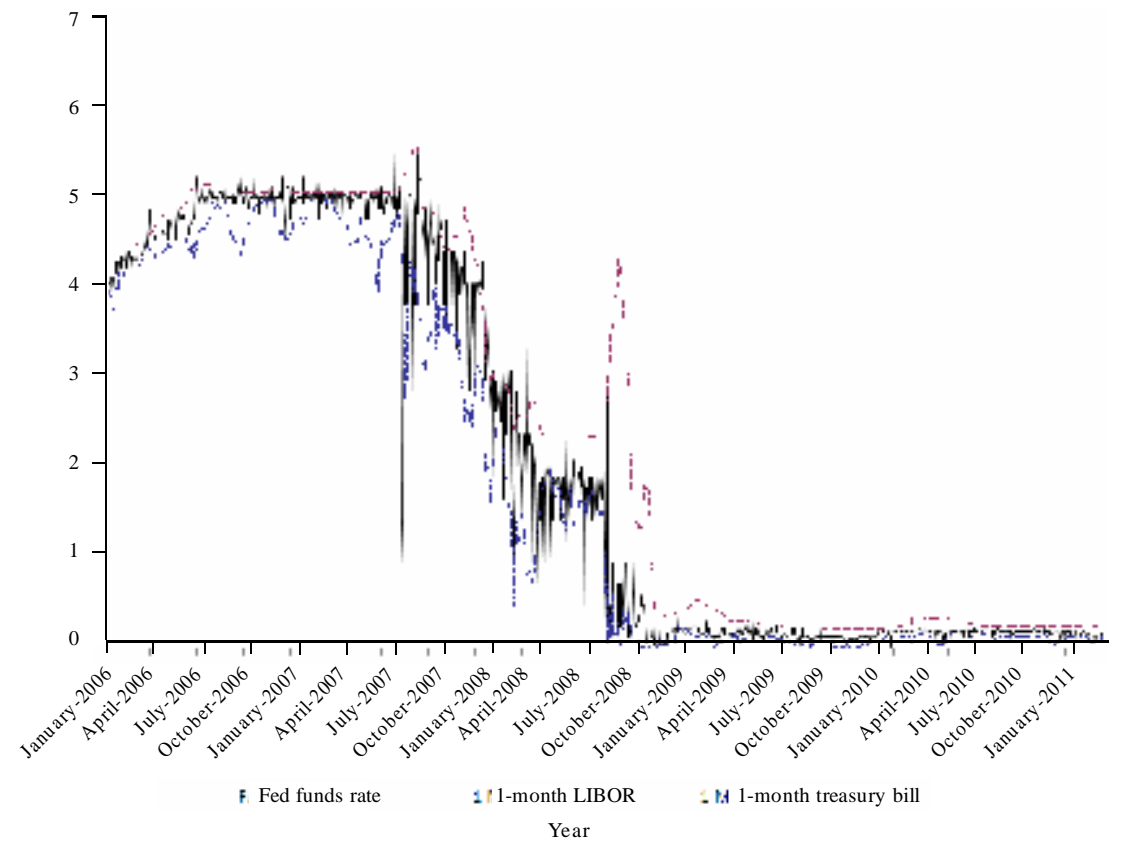

Sources: Federal Reserve Economic Data and Bloomberg. 
Figure 3. The Nominal Broad Dollar Index Movements

(J anuary $2002=100$ )

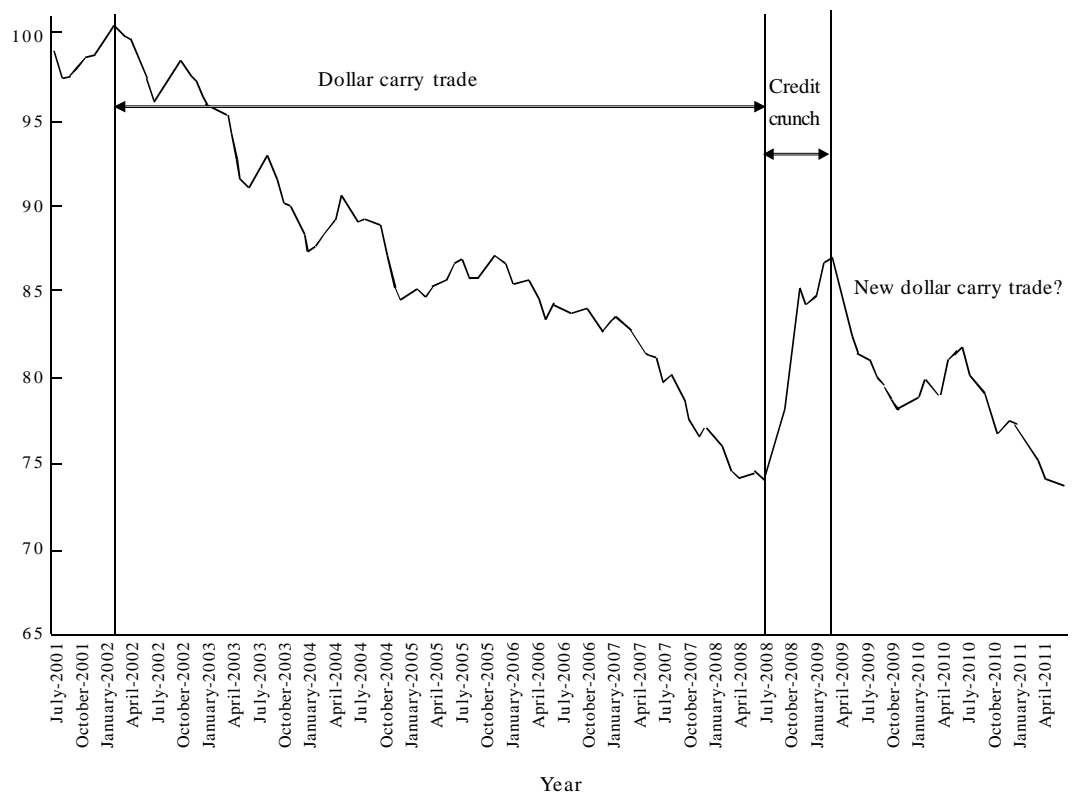

Source: Federal Reserve Economic Data.

the Fed keeping interest rates, on average, below those prevailing in most industrial countries, and much below those prevailing in EM. The federal funds rate had been reduced to just 1 percent in 2003-2004 and the Fed was very slow to increase it before the 2008 crisis; Since then, the US has had near-zero short-term interest rates from late 2008 onward. For EM only, Figure 4 is the mirror image of Figure 3, and shows their ongoing nominal appreciation since 2002, as the counterpart of the dollar's slow depreciation. Figure 5 shows that China's modest appreciation from 2002 to 2011 cumulated to be about the same as other EM, but the upward course of the RMB has been smoother and more predictable.

The combination of very low American interest rates and a declining dollar has provoked large outflows of financial capital ("hot" money) into EM for almost a decade. When EM exchange rates are not tied down by official parities, their endogenous ongoing appreciation induces even more hot money inflows. Trend-following (chartist) speculators see a double benefit: the higher EM interest rates combined with their currencies appreciating against the dollar or yen. For 2000-2007 before the global credit crunch in 2008, Table 1 provides illustrative returns to borrowing in dollars, euros or yen to invest in surrounding EM. The annual returns to dollar based carry traders investing in Brazil, Mexico and Canada were about 7.9 percent.

For EM, therefore, exchange rate flexibility is no protection from foreign interest rate 
Figure 4. EM Real Nominal Exchange Rate Appreciation

(J anuary $2005=100$ )

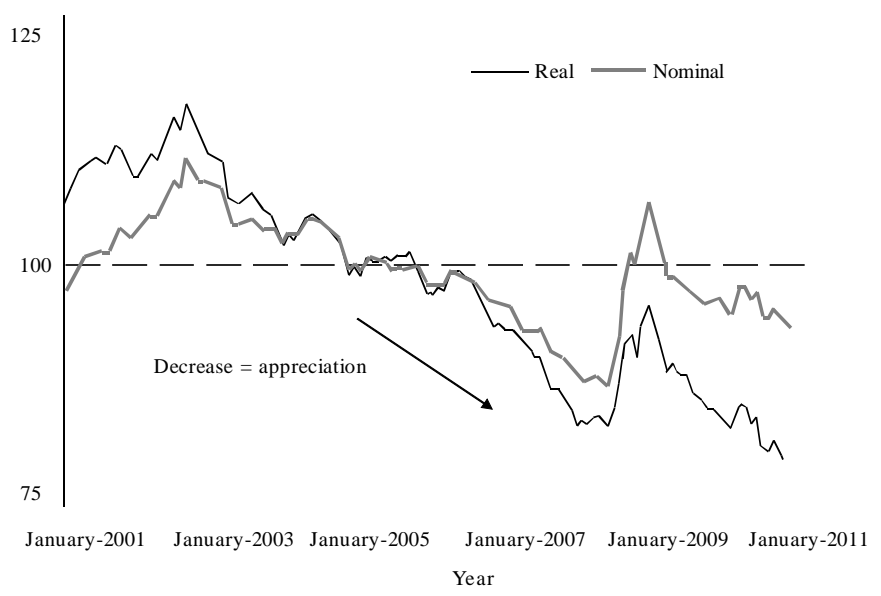

Source: Haver Analytics, Morgan Stanley Research.

N otes: Emerging markets (EM) include the following countries: Russia, Poland, Czech Republic, Hungary, Romania, Ukraine, Turkey, Israel, UAE, Saudi Arabia, South Africa, China, India, Hong Kong, Korea, Taiwan, Singapore, Indonesia, Malaysia, Thailand, Brazil, Mexico, Chile, Peru, Colombia, Argentina and Venezuela.

Figure 5. EM and CHN Nominal Exchange Rate Appreciation $(J$ anuary $2005=100)$

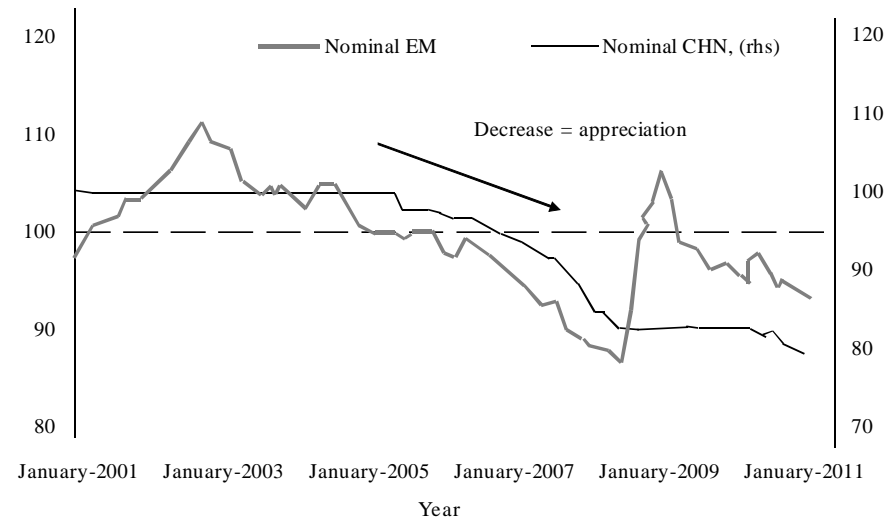

Source: Haver Analytics, Morgan Stanley Research.

disturbances, as when the Fed reduces its short rates to zero. In the short run, exchange rate flexibility may actually enhance the returns that carry traders see as the target EM currency appreciates against the dollar. To slow the appreciations of EM currencies, EM central banks typically intervene to buy dollars with domestic base money. And these interventions have been truly massive. Figure 6 shows that from the first quarter of 2001 to the first quarter of 2011, the dollar value of EM foreign exchange reserves rose sixfold from 
Table 1. Returns on Carry Trade (2000 - 2007)

\begin{tabular}{l|c|c|c|c|l}
\hline \multirow{2}{*}{ F und ing cur rency } & \multicolumn{2}{|c|}{ I nterest rates } & $\begin{array}{c}\text { Returns from } \\
\text { appreciation }\end{array}$ & $\begin{array}{c}\text { R eturns of car ry } \\
\text { trades }\end{array}$ & Investment cur rencies \\
\cline { 2 - 3 } & Funding & I nvestment & 1.1 & 7.9 & Brazil, Mexico and Canada \\
\hline US dollar & 3.4 & 10.2 & 1.0 & 5.2 & Iceland, Poland and Czech Republic \\
\hline Euro & 3.2 & 7.4 & 5.2 & 10.7 & Australia, Korea and New Zealand \\
\hline Japanese yen & 0.1 & 5.3 & &
\end{tabular}

Source: IMF.

Figure 6. Foreign Exchange Reserves

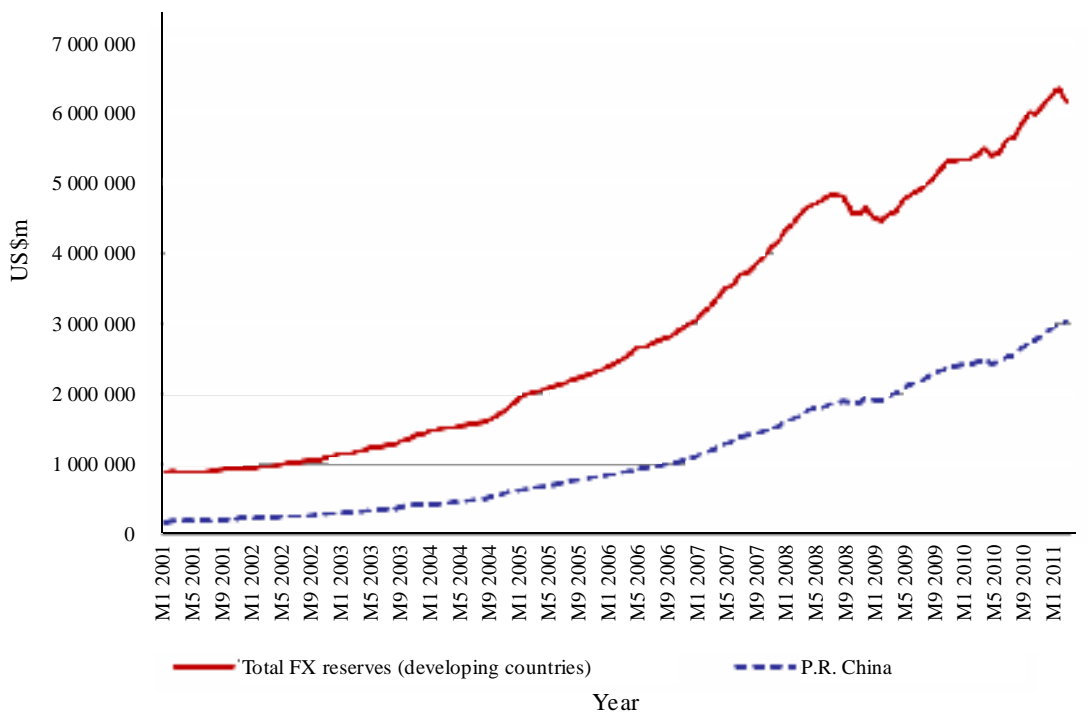

Source: IFS.

N otes: Emerging Markets (EM) include the following countries: Russia, Poland, Czech Republic, Hungary, Romania, Ukraine, Turkey, Israel, UAE, Saudi Arabia, South Africa, China, India, Hong Kong, Korea, Singapore, Indonesia, Malaysia, Thailand, Brazil, Mexico, Chile, Peru, Colombia, Argentina and Venezuela.

US\$1tn to US\$6tn! Figure 6 also shows that China accounted for about half of this huge buildup, but the collectivity of other EMs was equally important.

Figure 7 shows that this EM buildup of foreign exchange reserves increased much faster than the growth of their nominal GDPs. For the EM group, reserves rose from approximately 15 percent of GDP at the beginning of 2001 to 34 percent of GDP at the beginning of 2011. For China alone over this same 10-year period, Figure 7 shows that the ratio of FX reserves to GDP increased particularly strongly, from approximately 13 to 50 percent. Some EM, notably China and Brazil, have re-imposed exchange controls on capital inflows, but with limited success.

This sharp buildup of EM foreign exchange reserves has been too big to be fully offset by domestic monetary sterilization operations. The resulting loss of monetary control in the EM led (and leads) to inflation generally higher than that in the developed market 
Figure 7. FX Reserve - GDP Ratio

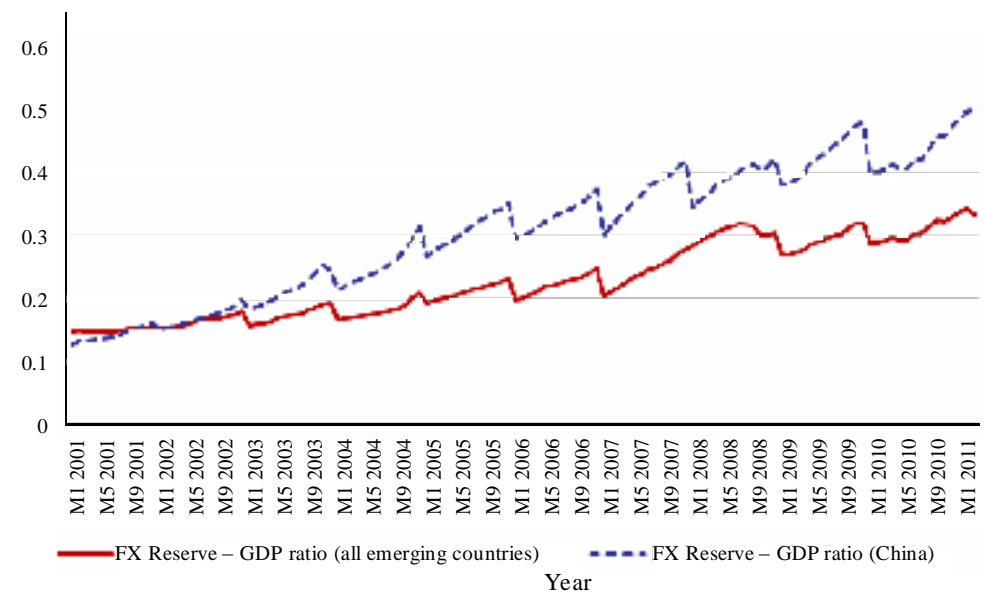

Source: IFS.

N otes: The ratio uses annual GDP of the corresponding year in the denominator. The months in 2011 use 2010 GDP in the denominator. Emerging markets (EM) include the following countries: Russia, Poland, Czech Republic, Hungary, Romania, Ukraine, Turkey, Israel, UAE, Saudi Arabia, South Africa, China, India, Hong Kong, Korea, Singapore, Indonesia, Malaysia, Thailand, Brazil, Mexico, Chile, Peru, Colombia, Argentina and Venezuela

\section{Figure 8. Emerging Markets (EM) and} Developed Markets (DM) Inflation

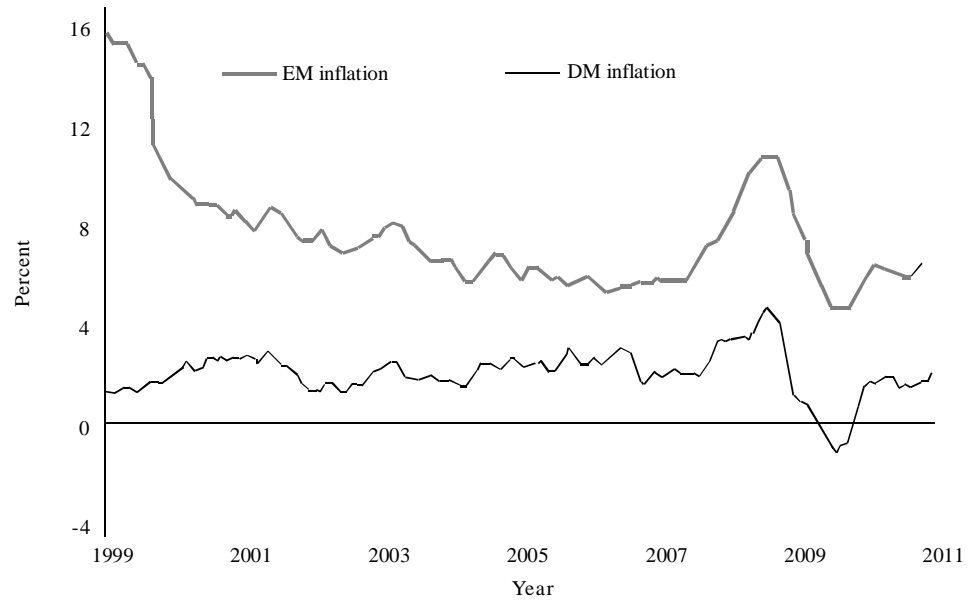

Source: Haver Analytics, Morgan Stanley Research.

N otes: Developed markets (DM) include the following countries: the USA, Germany, France, Italy, Spain, Japan, the UK, Canada, Sweden and Australia.

economies (DM), as shown in Figure 8. This greater inflation in EM occurred despite the fact that, since 2002, EM currencies on average appreciated against the DM currencies, as 
Table 2. Foreign Exchange Reserves (US\$m)

\begin{tabular}{|c|c|c|c|c|c|}
\hline Date & China & R ussian feder ation & Indonesia & India & Brazil \\
\hline M5 2009 & 2089490 & 385738 & 55430 & 251456 & 194209 \\
\hline M6 2009 & 2131610 & 394186 & 55122 & 254093 & 199900 \\
\hline M7 2009 & 2174620 & 383170 & 54971 & 260631 & 205169 \\
\hline M8 2009 & 2210830 & 383044 & 55440 & 261247 & 209998 \\
\hline M9 2009 & 2272590 & 383578 & 56955 & 264373 & 215336 \\
\hline M10 2009 & 2328270 & 403048 & 59058 & 266768 & 224763 \\
\hline M11 2009 & 2388790 & 413573 & 60034 & 263191 & 230087 \\
\hline M12 2009 & 2399150 & 405825 & 60572 & 258583 & 231888 \\
\hline M1 2010 & 2415220 & 402778 & 64039 & 256362 & 233889 \\
\hline M2 2010 & 2424590 & 402750 & 64220 & 253991 & 234531 \\
\hline M3 2010 & 2447080 & 412834 & 66326 & 254685 & 237029 \\
\hline M4 2010 & 2490510 & 425126 & 72966 & 254773 & 240481 \\
\hline M5 2010 & 2439510 & 418808 & 68940 & 247951 & 242874 \\
\hline M6 2010 & 2454280 & 422778 & 70609 & 249628 & 246025 \\
\hline M7 2010 & 2538890 & 437551 & 73163 & 258551 & 250107 \\
\hline M8 2010 & 2547840 & 436647 & 75540 & 256227 & 254082 \\
\hline M9 2010 & 2648300 & 447567 & 80520 & 265231 & 267717 \\
\hline M10 2010 & $27+60900$ & 452905 & 85674 & 269093 & 277212 \\
\hline M11 2010 & 2767810 & 438237 & 86653 & 263281 & 277885 \\
\hline M12 2010 & 2847340 & 432949 & 89970 & 267814 & 280570 \\
\hline M1 2011 & 2931670 & 439969 & 89252 & 269893 & 289497 \\
\hline M2 2011 & 2991390 & 447175 & 93333 & 271988 & 299176 \\
\hline M3 2011 & 3044670 & 454223 & 99350 & 274330 & 308578 \\
\hline M4 2011 & NA & 471725 & NA & NA & 319233 \\
\hline M5 2011 & NA & NA & NA & NA & NA \\
\hline $\begin{array}{l}\text { Percentage increase } \\
\text { from May } 2009\end{array}$ & 46 & 22 & 79 & 9 & 59 \\
\hline
\end{tabular}

Source: IFS.

N ote: NA, not available.

shown in Figure 4.

More recently, after the interruption of the 2008 global credit crunch, a renewed carry trade began and was led by the now zero short-term interest rates in the USA. Table 2 shows the continued rapid buildup of foreign exchange reserves from May 2009 into 2011 in the largest EMs (China, Russia, Indonesia, India and Brazil), all of whom have nominal CPIs growing more than 5 percent per year. This is substantially higher than CPI or PPI inflation in Europe, or Japan, or in the US itself. China's ongoing trade surplus (without any normal offsetting capital outflow) also contributes to its buildup of foreign exchange reserves, but is no longer dominant.

Stephen Green of Standard Chartered Bank shows (Figure 9) that net financial inflows into China in the last quarter of 2010 were much bigger than its trade surplus. In the first quarter of 2011, Green (2011) estimates that China's foreign exchange reserves rose by US $\$ 152 \mathrm{bn}$ even though its trade surplus was negligible. Hot money inflows now seem to be the main source of China's increased foreign exchange reserves, as they were in the first half of 2008 (Figure 9) before the global credit crunch took hold in the second half of 2008.

On a world scale, the most striking inflationary impulse is seen in primary commodity prices. As of 20 August 2011, the Economist's dollar Commodity Price Index for all items has increased 106.7 percent, and food alone 124.5 percent, since 2005. Figure 10 gives a longer 
Figure 9. Components of China's Foreign Exchange Reserve Growth

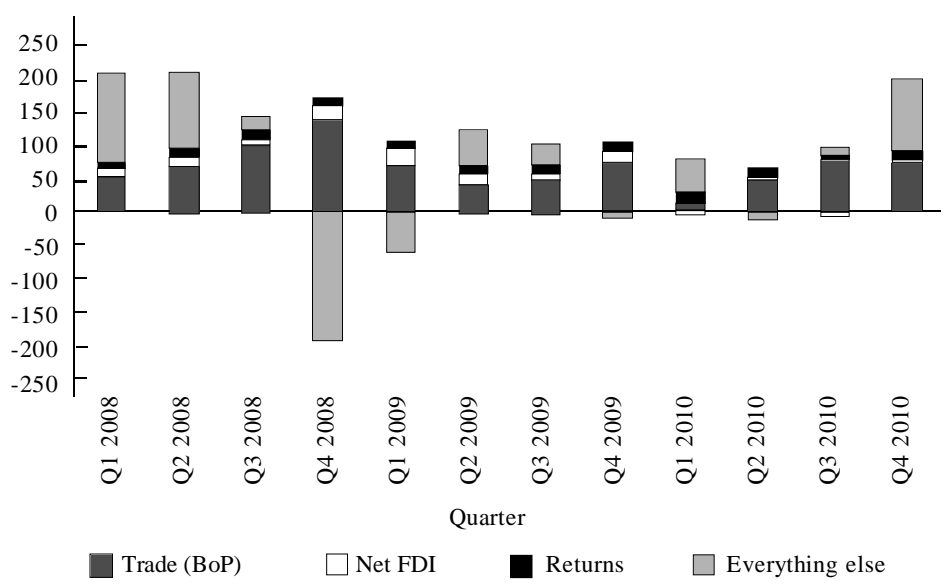

Source: Standard Chartered.

Figure 10. The Greenspan-Bernanke Bubble Economy

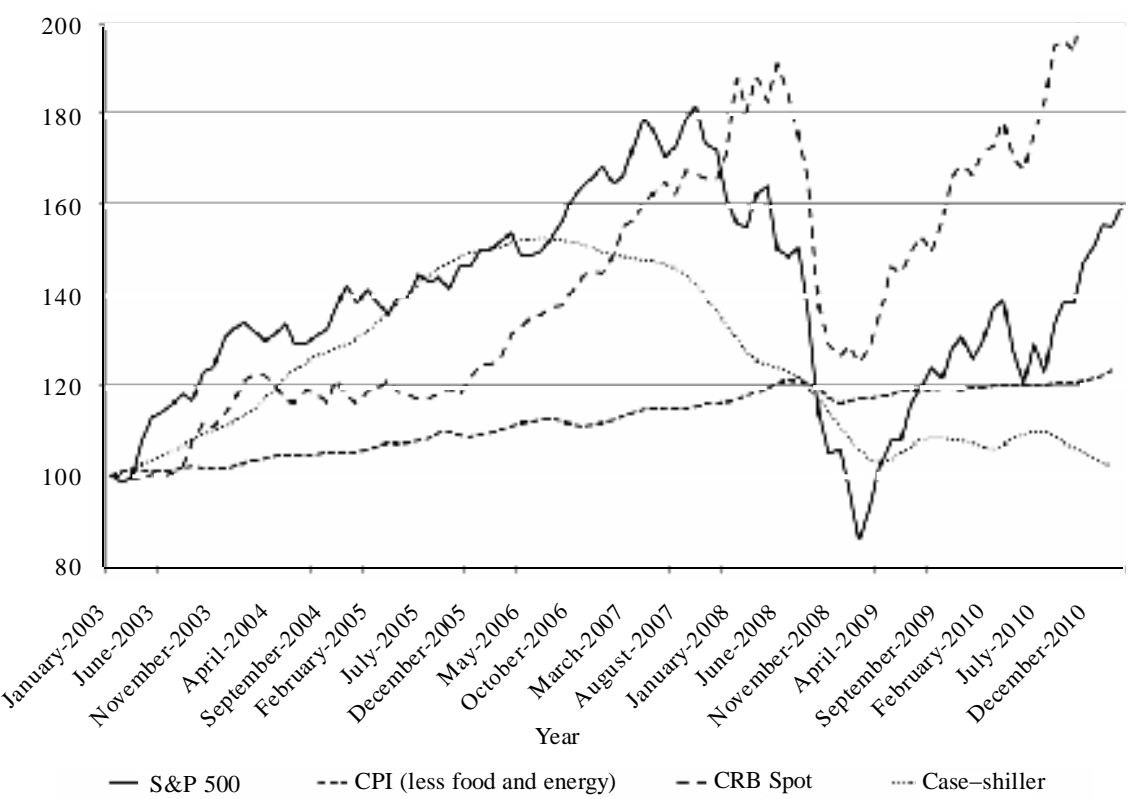

Source: Bloomberg and Federal Reserve Economic Data.

perspective on various asset price bubbles for the past decade, including two extraordinary surges in commodity prices before and after the global credit crunch of 2008.

Near-zero interest rates in the mature industrial countries contribute to commodity 
price inflation in two ways. First, they generate hot money inflows into the EM periphery, as analyzed here, and EM demand for primary commodities rises. Second, once commodity prices begin to rise, "commodity" carry traders find that they can borrow ultra cheaply in New York or Tokyo to fund long positions in commodity futures. Of course, this adds to the upward price momentum making commodity prices, and asset prices in general, more prone to bubbles, as a glance at Figure 10 would suggest.

However, also notice from Figure 10 that the US "core" CPI index, which excludes food and energy prices, has yet (in June 2011) to register any of this inflationary pressure. This backward-looking index, which includes the post-bubble downward fall in house prices and rents, is the Fed's favorite inflation target! With the Fed looking the other way, this international inflation will eventually, albeit with a lag of somewhat uncertain duration, come back to the US and other mature industrial countries, perhaps in the form of "stagflation" reminiscent of the 1970s (McKinnon, 2011b).

\section{Carry Trades and International Monetary Reform}

What are the implications for international monetary reform? In the new millennium, I have argued that world monetary instability has been (and is) provoked by large and persistent interest differentials that induce "carry trades": the willingness of speculators to borrow in low-interest rate currencies (source currencies) to invest in higher yield currencies (investment currencies). What can governments do about this?

First some economic history. In 1945, the US was the only industrial country to survive the war with its financial system intact. The dollar was convertible on both current and capital accounts, and inflation was moderate. The Western European countries and Japan had open or repressed inflation - and detailed balance of payments restrictions on both importing and exporting as well as on capital flows. So right away the dollar became the key currency for international transacting.

But initially, the dollar's legal status as key currency was not recognized. In 1944 when the Bretton Woods agreement was first negotiated, all currencies were defined in terms of gold. The "1944 gold dollar" was the prevailing unit of account. The US par value was 0.888671 grams or $1 / 35$ ounces, and other currencies were defined similarly. There was complete symmetry in the Articles with respect to exchange rate fixing.

However, the Bretton Woods agreement did not really recognize the underlying reality of the dollar as key currency until after the IMF had been set up in 1945. Then the Board issued a by-law, which stated that any country that was keeping a convertible currency within the prescribed limits (1-percent margins) vis-à-vis any member that was tied to gold, 
would be deemed to be fulfilling its fixed exchange rate obligation under Article IV. ${ }^{1}$ Then virtually all member countries opted to peg to the dollar as the key or central currency. This left the US without an exchange rate obligation (other than its gold parity, which was suspended in 1971) or target of its own.

This asymmetry persists to the present day, long after official exchange rate parities were suspended. Other countries may or may not intervene in the foreign exchanges, although today's emerging markets are heavy interveners, as shown by their massive buildup of foreign exchange in Figure 6, while the US stays passive except in emergencies. Because the US in 1945 had accumulated virtually all the world's monetary gold, nobody then believed that this residual gold parity obligation would ever constrain American behavior.

The new IMF provided financial wherewithall to help other countries maintain their dollar parities as they moved toward current-account convertibility and freer multilateral trade. By 1950, the system of fixed (but adjustable) dollar parities, and current-account convertibility under the IMF's Article VIII was in place. This dollar anchor became the monetary basis for the dramatic postwar economic growth of the industrial countries in the 1950s and 1960s - most unlike the shambolic monetary aftermath of World War I.

However, one of the principal designers of Bretton Woods, John Maynard Keynes was adamant that capital controls be retained to minimize cross-currency financial flows. Keynes wanted the new system to be insulated from the hot money flows characteristic of the 1920s and 1930s that had undermined, and then caused, the implosion of the inter-war gold standard leading to worldwide depression. Instead, Keynes wanted national macroeconomic autonomy (McKinnon, 1993), where each nation remained free to set its own interest rates and conduct its own fiscal policy to secure full employment without being bound by an international standard. Therefore, to this day, under the IMF Articles of Agreement, any signatory is free to impose exchange restrictions on its capital account. Although legal for all countries, the US itself could not possibly impose capital controls. Because the dollar is the key currency, the whole system of clearing international payments multilaterally would collapse.

From 1945 to the late 1960s, most industrial countries and virtually all developing ones kept capital controls in place. However, unlike what Keynes wanted or projected, a common international monetary standard was re-established. The stable-valued dollar became the common anchor for keeping national price levels roughly aligned, and the need for dramatically different interest rates was minimal. Although imperfect, the old system of

\footnotetext{
${ }^{1}$ I am greatly indebted to Robert Mundell for clarifying these points.
} 
fixed dollar parities eliminated the possibility of prolonged exchange rate movements in one direction on which carry traders now thrive.

Compared to the 1950s and 1960s, today's worldwide carry-trade problem has become more acute because exchange rates are more flexible and because of the relaxation of controls on international movements of financial capital, at least in part at the misguided behest of the IMF as a necessary step toward economic "liberalization." (However, illiquid longer-term direct foreign investments are not a problem.) Fortunately, over the past year, the IMF seems to have reversed itself and is more tolerant of controls on liquid international capital flows, but only after a lot damage had been done.

The Asian crisis of 1997-1998 was worsened by an earlier carry trade with Japan. By 1995, Japan had fallen into a near zero interest rate liquidity trap with a weakening yen. Hot money poured out of Japan and into the Asian Crisis Five: Indonesia, Korea, Malaysia, Philippines and Thailand. Although Japan was not the only source for over-borrowing by the Crisis Five, they became badly over-extended in their foreign-currency indebtedness. Thus, when speculators attacked Thailand in June 1997, the contagion spread to the other four by the end of the year, with capital flight, widespread financial bankruptcies, sharp exchange rate depreciations, and sharp downturns in output and employment. Japan was hurt as its exports to other East Asia slumped. Fortunately, China ignored foreign advice to depreciate the renminbi in tandem. Instead, the yuan/dollar rate was kept stable, which made it easier for its five smaller East Asian trading partners (and competitors) and Japan to recover.

Today, the carry-trade story is no better. The prolonged dollar depreciation after 2002 (Figure 3) with ultra-low US interest rates led to the huge buildup of foreign exchange reserves (Figure 6) in the EM. Similarly, over the past decade, misdirected pressure on China to continually appreciate the RMB has given carry traders a one-way bet on foreign exchange movements that they really love. Notice that this explanation differs from the common view (Rajan, 2011) that Asian countries were so badly burned by the 1997-1998 crisis that they turned conservative and resolved to run large trade surpluses to buildup of their foreign reserve positions. However, today's large size of Asian official exchange reserves is far in excess of any such prudential motivation and much larger than their cumulative trade surpluses.

\section{A New International Monetary Agreement?}

How best can carry trades be limited? Central bankers from the G-20 could meet continually to monitor each other in order to prevent wide interest differentials from developing. True to its newly professed virtue, the IMF should refrain from criticizing countries who attempt 
to impose capital controls to stem hot money flows. It could also provide technical advice on how to do so most efficiently.

If interest spreads are too wide, capital controls will always fail. The first item on the agenda would be to abandon monetary policies by the mature economies that set interest rates near zero, which pressures emerging markets to keep their interest rates low despite the inflationary pressure they now face. The Fed must be the leader in raising interest rates because, under the asymmetrical world dollar standard, it has the greatest autonomy in monetary policy.

However, American officials point to the stagnant US economy as the reason they want to keep domestic interest rates as low as possible - even zero. Thus, they have to be convinced that this common view is mistaken, and that raising short-term interest rates on dollar assets from zero to modest levels is in the US's own best interests, as well as that of the rest of the world.

\section{Relaxing the Supply Constraint on Bank Credit within the USA}

How do near-zero interest rates in US interbank markets constrict the economy? Since July 2008, the stock of base money in the US banking system has virtually tripled. As part of its rescue mission in the crisis and to drive interest rates down and flood markets with liquidity, the Fed has bought many nontraditional assets (mortgage-backed securities) as well as Treasuries. However, these drastic actions have not stimulated new bank lending. As shown in Figure 11, much of this huge increase in base money is now lodged as excess reserves (cash assets) in large American commercial banks: a liquidity trap. In addition, Figure 11 shows that banks have invested heavily in Treasury and agency securities.

Despite the Fed's strenuous efforts, the supply of ordinary bank credit to firms and households continues to fall as of early 2011. Figure 11 shows outstanding commercial and industrial loans falling from US $\$ 1.54$ tn in May 2008 tojust US \$1.24tn in March 2011. Although large corporate enterprises have recovered from the credit crunch of 2008 through their renewed access to bond and equity financing, bank credit is the principal source of finance for working capital for small and medium-sized enterprises (SMEs) enabling them to purchase labor and other supplies. In cyclical upswings, SMEs have traditionally been the main engines for increasing employment, but not in the very weak upswing of 2010-2011, where US employment gains have been meager or nonexistent.

Why should zero interest rates be causing a credit constraint in the US? After all, conventional thinking has it that the lower the interest rate the better credit can expand. This is only true when interest rates, particularly interbank interest rates, are comfortably 


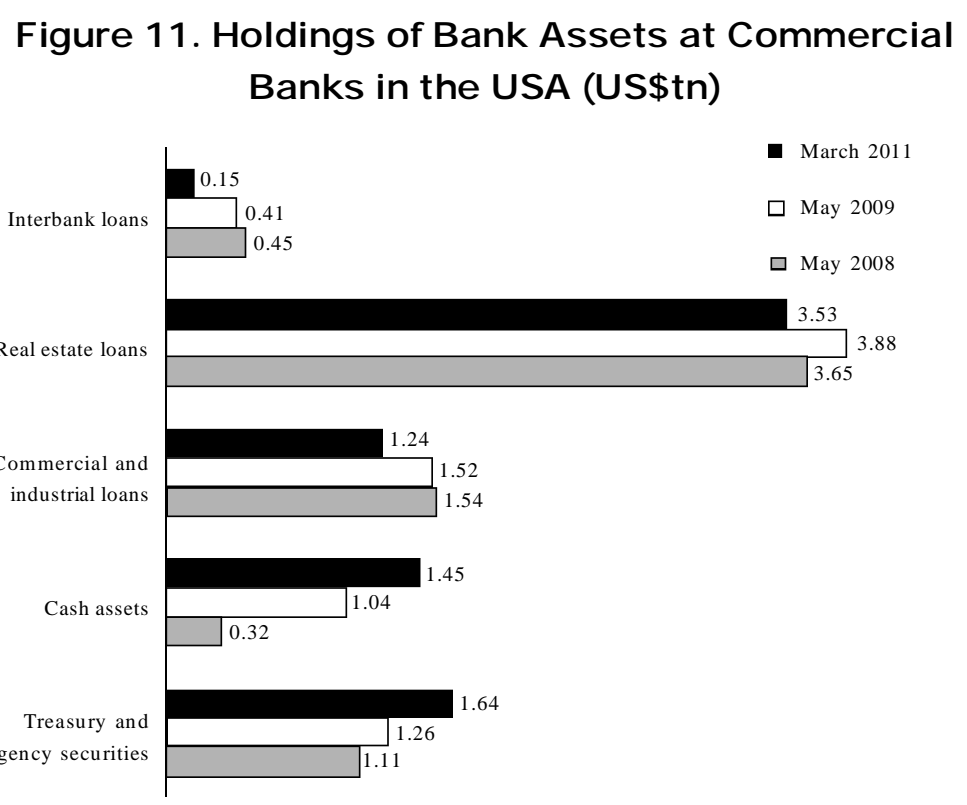

Source: Federal Reserve Economic Data.

above zero. Banks with good retail lending opportunities typically lend by opening credit lines to nonbank customers. However, these credit lines are open-ended in the sense that the commercial borrower can choose when, and by how much, he or she will actually draw on his or her credit line (subject to some maximum limit of course). This creates uncertainty for the bank in not knowing what its future cash positions will be. An illiquid bank could be in trouble if its customers simultaneously decided to draw down their credit lines.

However, if the "retail" bank has easy access to the "wholesale" interbank market, its liquidity is much improved. To cover unexpected liquidity shortfalls, it can borrow from banks with excess reserves with little or no credit checks. However, if the prevailing interbank lending rate is close to zero (as it is now), then large banks with surplus reserves become loathe to part with them for a derisory yield. Then smaller banks, which collectively are the biggest lenders to SMEs in the US, cannot easily bid for funds at an interest rate significantly above the prevailing interbank rate without inadvertently signaling that they might be in trouble, i.e. distress borrowers. And indeed counterparty risk in smaller banks remains substantial as almost 70 have failed so far this year. (Remember that the huge Fed and TARP bailouts of 2008-2009 were limited to large banks deemed too big to fail.)

That the American system of bank intermediation is essentially broken is reflected in the sharp fall in interbank lending. Figure 11 shows that interbank loans outstanding in 
March 2011 were only one-third of their level in May 2008, just before the crisis hit. How to fix bank intermediation and escape from the liquidity trap is a long story (McKinnon, 2009, 2011b). However, raising short-term interest rates above zero is an important part of the story.

\section{A Concluding Note on Stagflation in the USA}

The Fed's zero interest rate policy has worsened the situation and made escape to a more normal flow of bank intermediation more difficult. Without more lending to SMEs, domestic economic stagnation will continue even though inflation will take off.

The stagflation of the 1970s was brought on by unduly easy US monetary policy in conjunction with attempts to "talk" the dollar down (the Nixon shock of August 1971) leading to massive outflows of hot money that destabilized the monetary systems of America's trading partners (McKinnon, 1982) and generated worldwide inflation. Although today's stagflation is not identical, the similarities would seem to be more important than the differences.

Today's "shock" is the Fed's overreaction to the global downturn of 2008 by setting the short-term federal funds rate close to zero. The solution is more straightforward. The Fed should announce a program for gradually increasing the Fed funds rate to some modest target, say 2 percent. This should be accompanied by a definite program for reducing the counterparty risk in interbank lending to all banks but particularly small ones, possibly by allowing them to pledge loans to SMEs as collateral.

To better preserve financial and exchange rate stability in the transition, the big four central banks (the Fed, the European Central Bank, the Bank of England and the Bank of Japan) should move jointly and smoothly to phase in a common and minimum target, say 2 percent, for their basic short-term interbank rates. By escaping from liquidity traps which so impair the efficiency of domestic bank intermediation, and lessening the bubbles problem, the mature center would benefit along with the periphery.

Reducing the spread in interest rates between the center and periphery would dampen carry trades and hot money flows in an important way. However, it may not be sufficient to end them altogether. Hence, acknowledging the legitimacy of emerging markets using capital controls and other devices to dampen hot money inflows should be an important part of the new G-20 discussion. Indeed, central banks in the mature center could monitor their own commercial banks to help central banks on the periphery enforce their controls.

There is an important asymmetry here. Capital controls are not for everybody. In 
particular, the US, at the center of the world dollar standard, cannot itself impose capital controls without destroying the world's system for clearing international payments multilaterally. Thus, everybody has a vested interest in rehabilitating the unloved dollar standard with open US financial markets. The first of many necessary steps in the rehabilitation process is for the Fed to abandon any thought of a QE3 while phasing out its policy of keeping short rates near zero.

\section{References}

Green, Stephen, 2011, "China, in, out, shake it about," Global Research, Standard Chartered, 5 May. McKinnon, Ronald, 1982, "Currency substitution and instability in the world dollar standard," American Economic Review, Vol. 72, No. 3, pp. 320-33.

McKinnon, Ronald, 1993, "The rules of the game: International money in historical perspective," Journal of Economic Literature, Vol. 31, No.1, pp. 1-44.

McKinnon, Ronald, 2009, "Zero interest rates and the fall in U.S. bank lending," The Journal of Economic Asymmetries,

McKinnon, Ronald, 2011a, "Beggar-thy-neighbor interest rate policies," Journal of Policy Modeling, forthcoming.

McKinnon, Ronald, 2011b, "The return of stagflation," The Wall Street Journal, 24 May.

McKinnon, Ronald and Gunther Schnabl, 2009, "The case for stabilizing China's exchange rate: Setting the stage for fiscal expansion," China \& World Economy, Vol. 17, No. 1, pp. 1-32.

McKinnon, Ronald and Gunther Schnabl, 2011, "China and its dollar exchange rate: A worldwide stabilizing influence?" CESifo Working Papers No. 3449, May, Munich.

Qiao, Hong (Helen) 2007, "Exchange rate changes and trade balances under the dollar standard," Journal of Policy Modeling, Vol. 29, No. 5, pp. 765-82.

Rajan, Raghuram G., 2010, Fault Lines: How Hidden Fractures Still Threaten the World Economy, Princeton: Princeton University Press.

(Edited by Xiaoming Feng) 